\title{
False Chinch Bug Nysius raphanus Howard (Insecta: Hemiptera: Lygaeidae) ${ }^{1}$
}

\author{
Babu Panthi, Braden Evans, and Justin Renkema
}

\section{Introduction}

The false chinch bug, Nysius raphanus Howard, is a small, greyish, native North American herbivorous seed bug (Arnett 2000, Haviland and Bentley 2010) (Figure 1). It is recognized as the most serious pest among members of the genus Nysius (Demirel and Cranshaw 2006b), but reports of heavy infestations and serious crop damage are uncommon (Cranshaw 2007, Haviland and Bentley 2010, Whitworth et al. 2012). When damage occurs, it is associated with large aggregations of the false chinch bug following periods of drought or the removal of weed hosts (Cranshaw 2007, Blake 2010, Whitworth et al. 2012). The false chinch bug is highly polyphagous, though it has demonstrated a strong preference for mustards (Brassica spp. and Sinapis spp.) (Demirel and Cranshaw 2006b, Haviland and Bentley 2010, Whitworth et al. 2012).

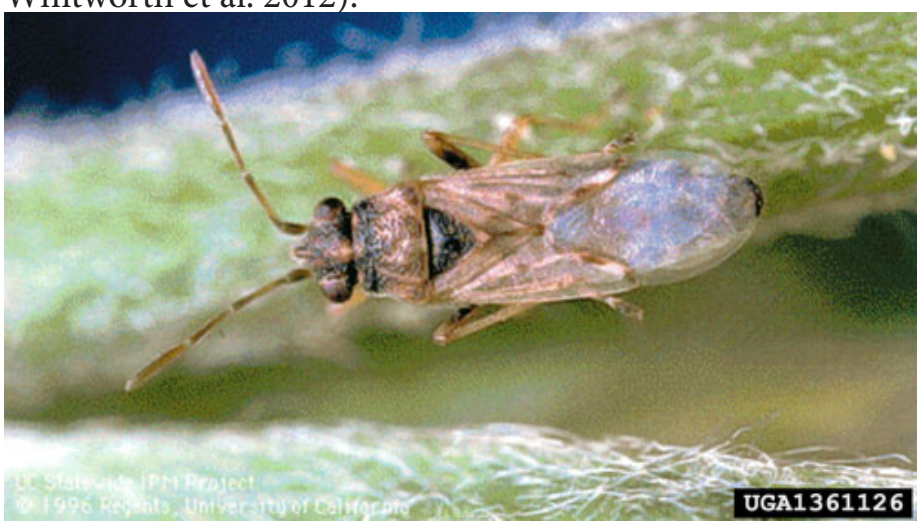

Figure 1. An adult false chinch bug, Nysius raphanus Howard.

Credits: University of California, Bugwood.org.
Due to its small size, inconspicuous coloration and relative abundance, the false chinch bug is often confused with other, similar species (Mead 2001). Most notable among these are of the seed bug superfamily Lygaeoidea such as the group of true chinch bugs, Blissus spp. (Hemiptera: Blissidae), bigeyed bugs, Geocoris spp. (Hemiptera: Geocoridae), and pamera bugs, Neopamera spp. (Hemiptera: Rhyparochromidae). The false chinch bug can be distinguished by its smaller size, grayish brown coloration and transparent wings, as compared to the larger black bodies and white wings of the true chinch bugs (Mead 2001) (Figure 3). Bigeyed bugs are wider with larger eyes and are considered to be beneficial predators that feed on pest insects and mites (Figure 4).

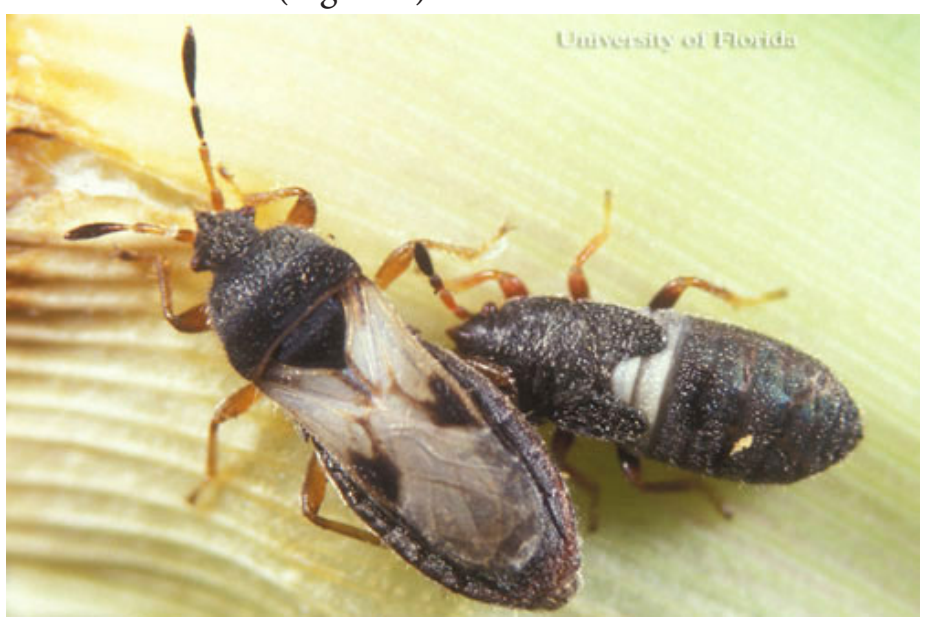

Figure 2. Adult and nymph stages of the false chinch bug, Nysius raphanus Howard.

Credits: Lyle J. Buss, UF/IFAS

1. This document is EENY-706, one of a series of the Department of Entomology and Nematology, UF/IFAS Extension. Original publication date May 2018. Visit the EDIS website at http://edis.ifas.ufl.edu. This document is also available on the Featured Creatures website at http://entnemdept.ifas.ufl.edu/ creatures/.

2. Babu Panthi, graduate research assistant; Braden Evans; and Justin Renkema, associate professor; Department of Entomology and Nematology, UF/ IFAS Gulf Coast REC, Wimauma, FL 33598.

The Institute of Food and Agricultural Sciences (IFAS) is an Equal Opportunity Institution authorized to provide research, educational information and other services

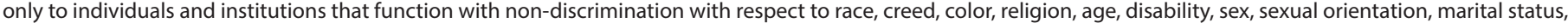

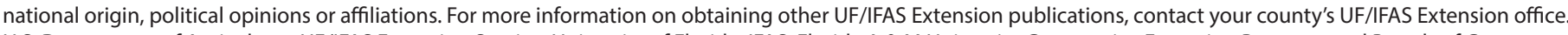
U.S. Department of Agriculture, UF/IFAS Extension Service, University of Florida, IFAS, Florida A \& M University Cooperative Extension Program, and Boards of County Commissioners Cooperating. Nick T. Place, dean for UF/IFAS Extension. 


\section{Distribution}

Originally described from a specimen in Kansas (Demirel and Cranshaw 2005, 2006a), the false chinch bug occurs widely throughout North America, Mexico, and the West Indies (Ashlock and Slater 1988). This species is most abundant in the southern and western United States, replaced by other, similar Nysius species elsewhere, including Nysius scutellatus in southern Florida, Nysius niger Baker in the midcentral United States, and Nysius angustatus, Nysius thyme Wolff, and Nysius groenlandicus Zetterstedt further north (Arnett 2000).

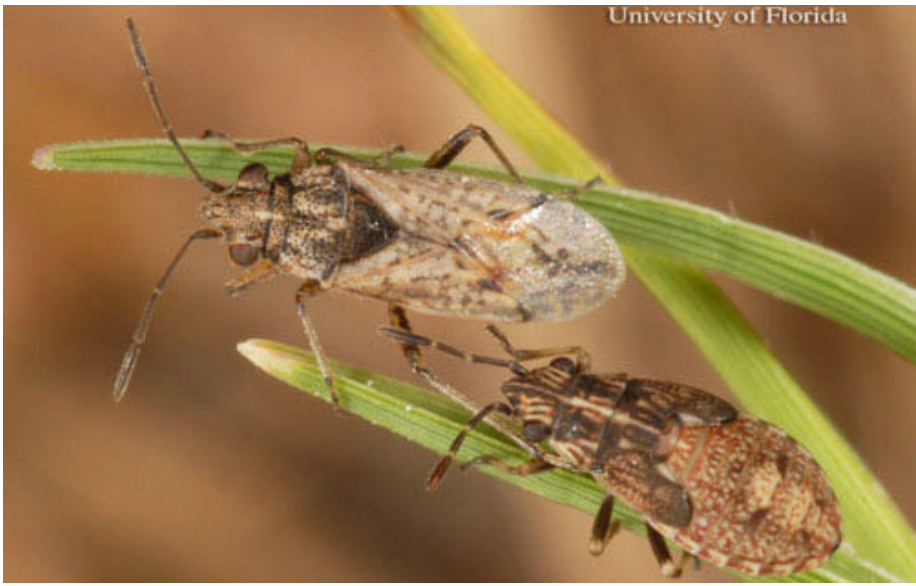

Figure 3. Adult and nymph stages of the true chinch bug, Blissus spp. Credits: Lyle J. Buss, UF/IFAS

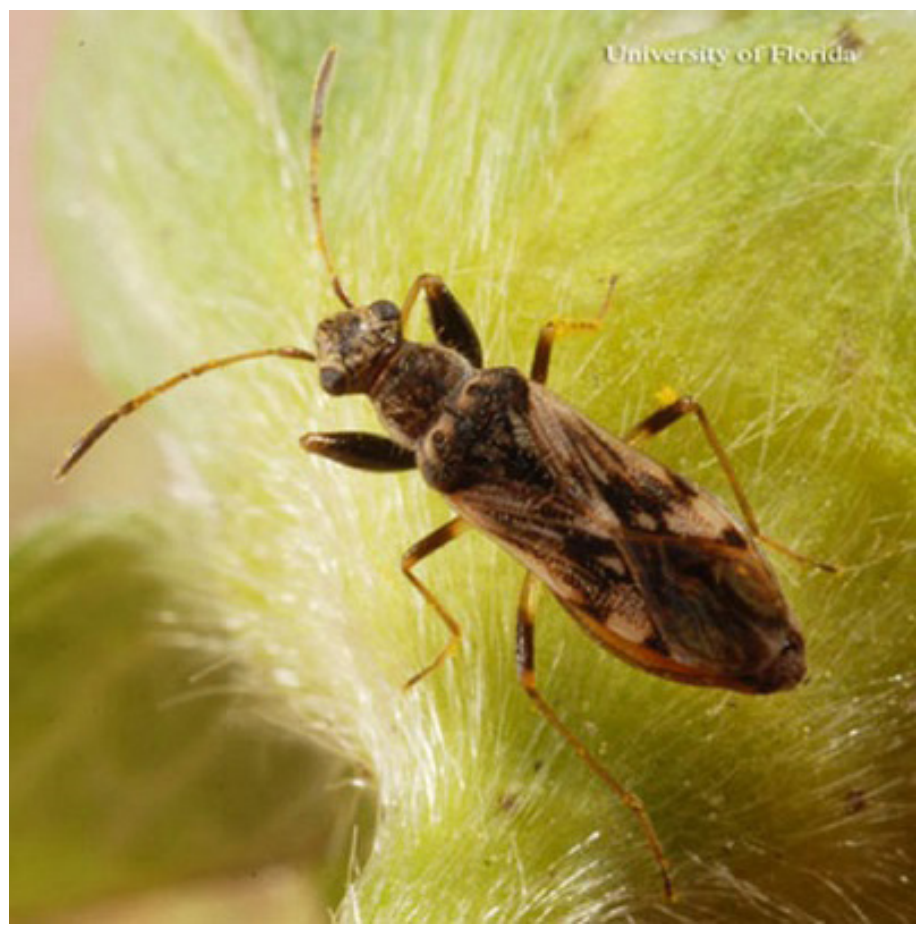

Figure 4. Adult pamera bug, Neopamera spp.

Credits: Lyle J. Buss, UF/IFAS

\section{Description and Life Cycle}

The false chinch bug is multivoltine, with up to three generations per year, and overwintering may occur in all life stages under leaf litter and other plant residue in uncultivated fields (Demirel and Cranshaw 2006b, Cranshaw 2007). Flixwood, a common weed in agricultural fields serves as winter host for this pest in Colorado (Cranshaw 2007) (Figure 5). Warming spring temperatures initiates activity in the false chinch bug including mating and oviposition. Large populations of the false chinch bug often go unnoticed in uncultivated fields (Whitworth 2012).

Infestations of the false chinch bug on cultivated crops typically result from the removal of host weeds, which can occur due to the onset of drought conditions or herbicide applications (Wene 1958). The absence of host plants triggers mass movements of false chinch bugs to the nearest succulent plants, which are often found in irrigated fields (Whitworth et al. 2012).

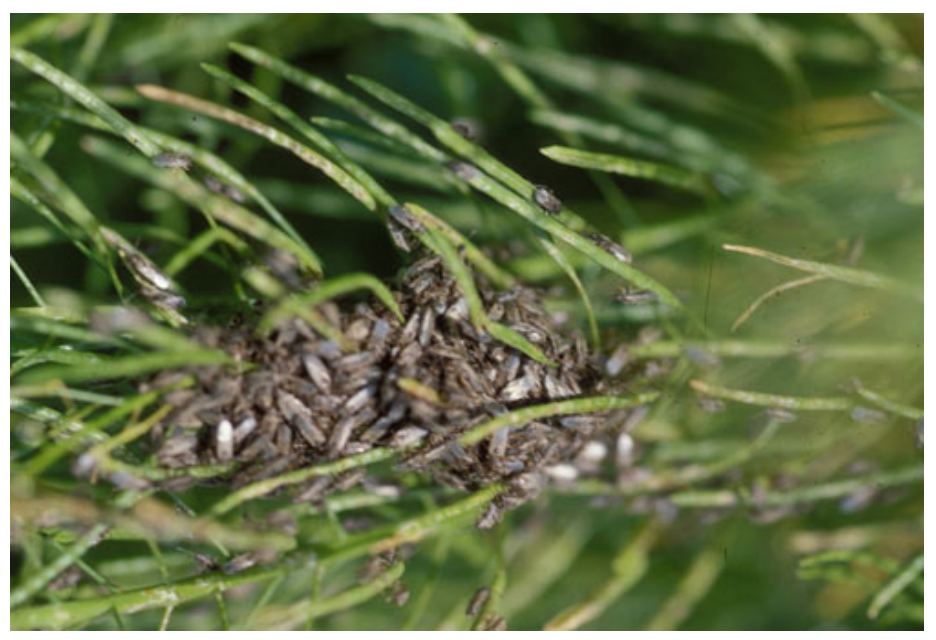

Figure 5. Aggregations of the false chinch bug adults, Nysius raphanus Howard, on flixwood, an important winter host in eastern Colorado. Credits: Whitney Cranshaw, Colorado State University, Bugwood.org.

\section{Eggs}

False chinch bug eggs have a pinkish hue, are $1.5 \mathrm{~mm}$ long and $0.4 \mathrm{~mm}$ wide. The eggs are laid in or near the soil around the base of host plants (Demirel and Cranshaw 2006a). Eggs have been observed in loose soil and on live plant material or leaf litter in contact with the soil surface (Whitworth et al. 2012).

\section{Nymphs}

Following egg hatch, the false chinch bug develops through five nymphal instars (stages), often observed in the leaf litter at the base of plants during the day (Whitworth et al. 2012). The nymphs resemble small, wingless adults with orange abdominal markings, becoming larger and darker 
mottled brown with each successive instar (Figure 2)

(Haviland and Bentley 2010).

\section{Adults}

The adult false chinch bug is mostly grey, with some brown markings. The adults are typically 3 to $4 \mathrm{~mm}$ long (Figures $1,2)$. The wings are thick and leathery anteriorly, and clear and membranous posteriorly, which is typical of Hemipterans (Haviland and Bentley 2010).

\section{Host Plants}

The false chinch bug usually occurs in uncultivated fields where it feeds on a variety of weeds preferentially crucifers (Brassicaceae). They also feed on a wide variety of cultivated crops preferably with flowers and seeds including potato, kochia, lettuce, pigweed, quinoa, and turfgrasses. Among cultivated crucifers, they feed on radish, canola and mustard greens (Barnes 1970, Cranshaw 2007). Commercial plantings attacked by the false chinch bug include field crops such as sorghum, soybean, corn, and cotton (Whitworth et al. 2012), as well as orchard seedlings such as pistachio, almond, citrus and pomegranate (Haviland et al. 2014, Varela et al. 2015). Feeding and damage on tobacco has been reported in Florida and Georgia (Tappan 1970). Aggregations and damage on strawberry was reported in southern Georgia in the winter of 2017 (David Curry unpublished results).

\section{Aggregations}

The false chinch bug is occasionally observed in large aggregations (Figures $6,7,8$ ). These aggregations typically result from the loss of a preferred food source, usually weeds of Brassica spp. (Leigh 1961, Byers 1973). Cool, wet, spring weather, which produces an abundance of succulent cruciferous weeds, in turn results in high rates of reproduction and recruitment among false chinch bugs. Such high populations often go unnoticed, because these insects remain on non-cultivated host plants. However, when these spring conditions are followed by a hot, dry, summer, weedy plants begin to dry and die off, resulting in mass migrations of false chinch bugs into areas with healthy plants, which is typical in irrigated commercial fields and orchards (Cranshaw 2007, Blake 2010, Haviland and Bentley 2010, Whitworth et al. 2012). At such high densities, false chinch bugs have been reported to cause severe damage to young almond, pistachio, citrus, and pomegranate trees (Blake 2010). High densities may also cause fruit malformation in strawberry and become a nuisance if they remain on field-packed fruit. Periods of severe drought drive false chinch bugs to seek the nearest available moisture, at times resulting in massive aggregations on irrigated lawns, gardens, and in and around buildings (Cranshaw 2007, Blake 2010, Whitworth et al. 2012).

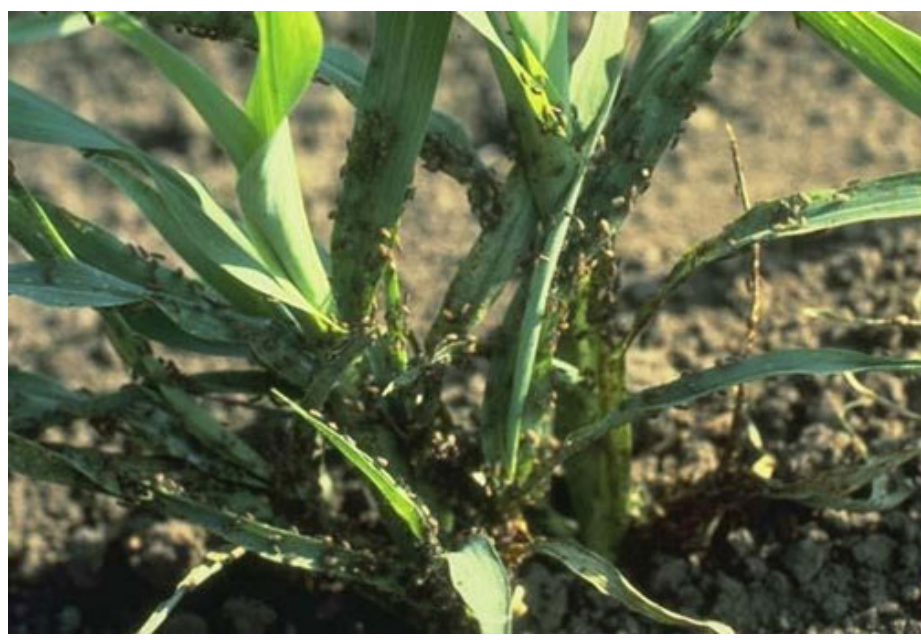

Figure 6. Aggregations of the false chinch bug, Nysius raphanus Howard, on sorghum.

Credits: Photograph by Kansas State University.

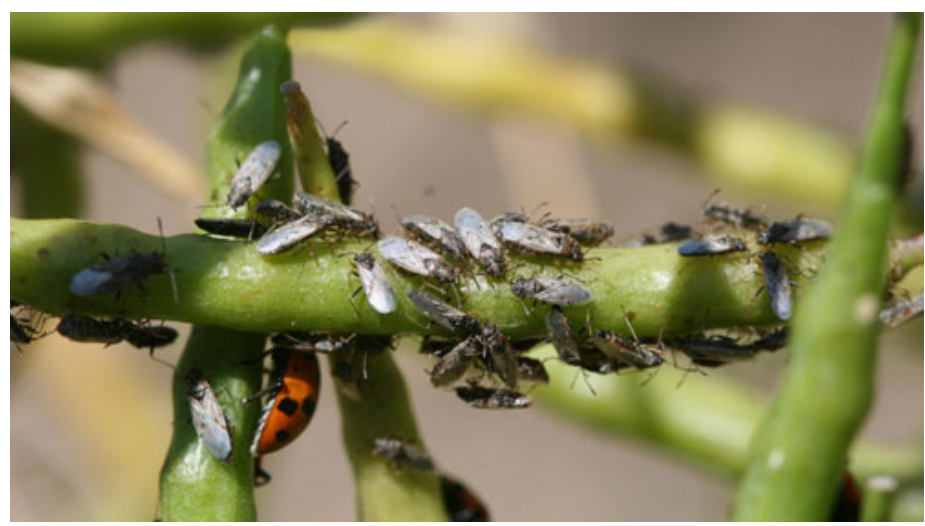

Figure 7. Aggregations of the false chinch bug, Nysius raphanus Howard, on canola seedpod.

Credits: Whitney Cranshaw, Colorado State University, Bugwood.org.

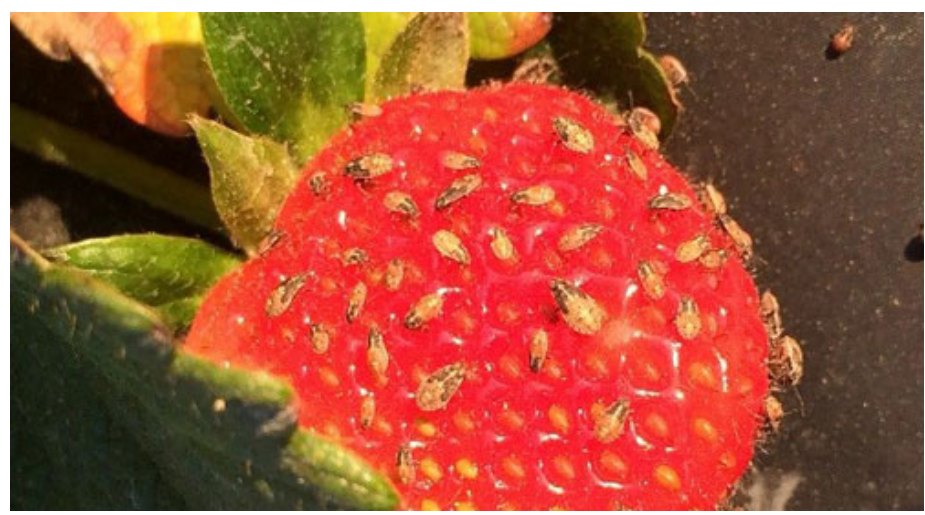

Figure 8. Aggregations of the false chinch bug, Nysius raphanus Howard, on strawberry.

Credits: David Curry, University of Georgia. 


\section{Damage}

The false chinch bug uses its piercing-sucking mouthparts to puncture stems, foliage, or fruits, then sucking the sap out of plants (Cranshaw 2007, Whitworth et al. 2012). When the false chinch bug occurs at low densities, plant damage is rarely reported. However, when large aggregations occur on plants, feeding damage can result in wilting, curling, and death of leaves, particularly newer growth (Cranshaw 2007, Whitworth et al. 2012) (Figure 9). Though feeding damage from false chinch bugs is rarely a concern for fruit and vegetable producers, unusually high aggregations have been reported to result in the death of young orchard seedlings (Blake 2006).

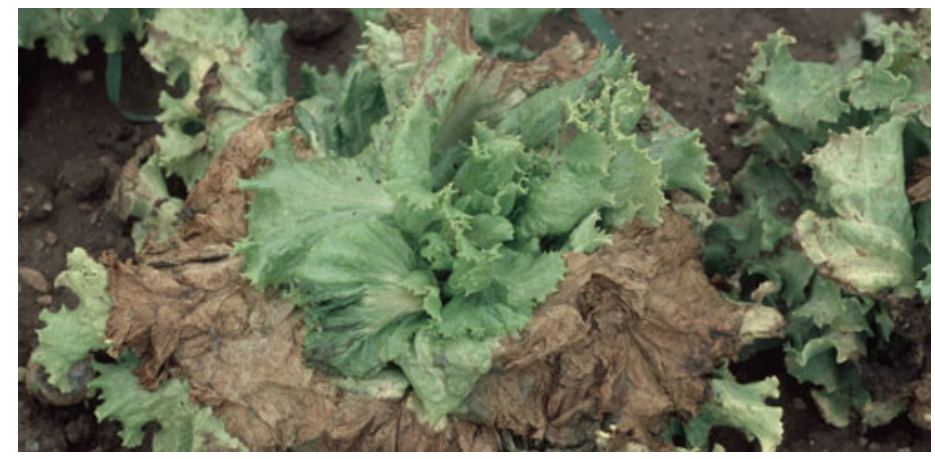

Figure 9. Wilting of lettuce caused by the false chinch bug, Nysius raphanus Howard.

Credits: Whitney Cranshaw, Colorado State University, Bugwood.org.

\section{Management}

The false chinch bug rarely requires management action on cultivated plants. However, when economically important aggregations occur, several chemical insecticides can successfully suppress pest-level populations (Haviland et al. 2014, Varela et al. 2015). At lower densities, or over smaller areas, using water to knock the insects off plants and drown them has been reported as an acceptable control method (Cranshaw 2007). To manage nuisance infestations in and around buildings, reducing irrigation of lawns and gardens during drought conditions is recommended, and windows and doors should be sealed to prevent entry into buildings (Cranshaw 2007). The removal of cruciferous weeds growing adjacent to cultivated fields should be done with an understanding that there is potential for the false chinch bug to migrate out of the area in search of other plants, and that a habitat for generalist natural enemies may be eliminated.

\section{Selected References}

Arnett RH. 2000. American Insects: A Handbook of the Insects of America North of Mexico, 2nd Ed. CRC Press. Florida, USA, 1024 pp.
Ashlock PD. 1977. New records and name changes of North American Lygaeidae (Hemiptera: Heteroptera: Lygaeidae). Proceedings of TIIF Entomological Society of Washington. 79: 575-582.

Ashlock PD, Slater A. 1988. Family Lygaeidae Schilling, 1829. The Seed Bugs and Chinch Bugs, pp. 167-245. In Henry TJ, Froeschner RC (eds.). Catalog of the Heteroptera, or True Bugs, of Canada and the Continental United States. E. J. Brill, Leiden. 958 pp.

Barnes MM. 1970. Genesis of pest: Nysius raphanus and Sisymbrium irio in vineyards. Journal of Economic Entomology. 63: 1462-1463.

Blake C. 2010. False chinch bug invasion in southern SJV. Western farm press. (4 April 2018)

Byers GW. 1973. A mating aggregation of Nysius raphanus (Hemiptera: Lygaeidae). Journal of Kansas Entomological Society. 46: 281-282.

Cranshaw W. 2007. False Chinch Bugs. Document 5.603. Colorado State University. (4 April 2018)

Demirel N, Cranshaw W. 2005. Evaluation of spring canolas and mustards of varying age for relative preference by false chinch bugs, Nysius raphanus (Howard). Pakistan Journal of Biological Sciences. 8: 665-668.

Demirel N, Cranshaw W. 2006a. Plant yield response to artificial infestation of the false chinch bug, Nysius raphanus, confined on spring canola. Phytoparasitica. 34: 477-485.

Demirel N, Cranshaw W. 2006b. Surveys of false chinch bug, Nysius raphanus (Howard) (Hemiptera: Lygaeidae) and their movement on cultivated crops and non-cultivated habitats throughout growing season in Colorado. Journal of Entomology. 3: 149-155.

Haviland DR, Bentley WJ. 2010. How to manage pests, pests in gardens and landscapes, False Chinch Bug. University of California Cooperative Extension. (4 April 2018)

Haviland DR, Bentley WJ, Beede RH, Daane KM. 2014. False Chinch Bug, Scientific name: Nysius raphanus, UC IPM Pest Management Guidelines: Pistachio, UC ANR Publication 3461. (4 April 2018) 
Leigh TF. 1961. Insecticidal susceptibility of Nysius raphanus, a pest of cotton. Journal of Economic Entomology. 54: $120-122$.

Mead FW. 2001. Bigeyed bugs (of Florida). Featured Creatures, University of Florida. Publication Number: EENY-252. (4 April 2018)

Tappan WB. 1970. Nysius raphanus attacking tobacco in Florida and Georgia. Journal of Economic Entomology. 63: 658-660.

Varela LG, Haviland DR, Bentley WJ, Zalom FG, Bettiga LJ, Smith RJ, Daane KM. 2015. False Chinch Bug, Scientific name: Nysius raphanus, UC IPM Pest Management Guidelines: Grape, UC ANR Publication 3448. (4 April 2018)

Wene GP. 1958. Control of Nysius raphanus Howard attacking vegetables. Journal of Economic Entomology 51: 250-251.

Whitworth RJ, McCornack B, Davis H. 2012. False chinch bug. Kansas State University Agricultural Experiment Station and Cooperative Extension Service. (4 April 2018) 